\title{
HUMAN RESOURCES DEVELOPMENT OF SHARIA BANKING: PHENOMENOLOGICAL APPROACH
}

\author{
Burhanuddin Yusuf ${ }^{1}$
}

\begin{abstract}
Human Resources Development of Sharia Banking: Phenomenological Approach. The aims of this study are to finding, identifying and mapping the condition and situation of the policy and practice of Human Resource Management. This study used a qualitative method with phenomenological approach to uncover the professional development of HR qualify. Data analysis techniques includes reduction, data display, perform verification, and compiling data to draw the conclusions. The study concluded that the conditions of management and human resource development three sharia Bank in Jakarta refers to the philosophy and principles of Islamic economics as well as guided by the vision and mission of sharia banks. This study find that sharia HR professional qualification characterised by quality of faith, piety, knowledge and understanding of finance and business, applying the principles of Islam and has a strong commitment to apply the rules of sharia, noble, hard-working, and sincerely intelligent accompanied by sincere
\end{abstract}

Keywords: Sharia Banking, Human Resource Development, Phenomenological

Abstrak. Pengembangan Sumber Daya Manusia Perbankan Syariab: Pendekatan Fenomenologis. Tujuan dari kajian ini adalah untuk menemukan, mengidentifiaksi, dan memetakan kondisi dan situasi dari kebijakan dan praktik manajemen sumber daya manusia. Kajian ini menggunakan metode kualitatif dengan pendekatan fenomenologis untuk melihat pengembangan atas kualifikasi sumber daya manusia. Teknik analisis data mencakup reduksi, tampilan data, verifikasi kinerja, dan kompilasi data untuk membentuk suatu kesimpulan. Kajian ini menunjukkan bahwa kondisi manajemen dan pengembangan sumber daya manusia di tiga bank syariah merujuk pada filosofi dan prinsip ekonomi syariah sebagaimana yang ditunjukkan oleh visi dan misi bank syariah. Temuan lain menunjukkan bahwa kualifikasi sumber daya professional memiliki karakteristik atas kualitas keyakinan, kesalehan, pengetahuan, dan pemahaman akan keuangan dan bisnis, aplikasi prinsip syariah dan memiliki komitmen kuat untuk mengaplikasikan aturan syariah, mulia, pekerja kerja, dan cerdas yang diiringi dengan ketulusan sikap.

Kata Kunci: Bank Syariah, sumber daya manusia, fenomenologis

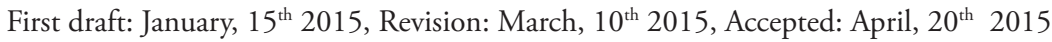

${ }^{1}$ Syarif Hidayatullah State Islamic University. Jl. Ir. H. Juanda No. 95, Ciputat, South Tangerang, Banten, Indonesia.

Email: burhanuddin.yusuf@uinjkt.ac.id 


\section{Introduction}

Nowadays, especially in the globalization era increasingly intense competition among companies, the more we realize the importance of human resource management and development of professionalism, including the Islamic banking industry in Indonesia. This paper is going to analyze the human resource development in three Islamic banks in Indonesia such as Bank of Muamalat, Bank of BNI Syariah, and Bank of Syariah Mandiri. In Indonesia, the development of Islamic banking system is developed base on dual banking system framework; this system is related with Indonesian Banking Architecture. On this system there is integration between Islamic banking and conventional banking to make a synergy cooperation to help the people for increasing the credit or financing for national productive sector.

The delopment of Islamic banking industry faced the tight competition, so the competency of human resources on Islamic banking must be improve. Until the 2014, the Islamic banking industry has 11 Islamic commercial banks, 23 Islamic banking unit, and 163 Islamic rural banks. Islamic banking industry has growing rapidly, but in the last year the growth of Islamic banking industry is decreasing.

The Islamic banking industry needs the qualified human resources which have multi-knowledge and multi-skills. The qualified human resources are needed by the Islamic banking industry to manage the banks to improve the profit of Islamic banking industry. The human resources in Islamic banks must to be creative and innovative to develop and modified the banking's product. The human resources in Islamic banking industry must to have the competency as an expertise in Islamic banking and finance, besides that must to understand the shariah contract, so he can modified the product that fulfill the shariah compliance. The Islamic human resources must be able to give a services and confince the sociecty that the Islamic banking product has suitable with Islamic ethics and principle. The human resources in Islamic banking industry must to have a competency in financial investement, banking, soft skills, and sharia. But this condition is rare in Islamic banking industry. This problem is established because the limitation of educational and training institution on Islamic banking.

The fact shows that almost the human resources on Islamic banks, especially at middle or top management is come from conventional banks. It predicted that almost 70 percent of Islamic banks employee today is come from conventional banks or from non-shariah economics education (Bank of Indonesia, 2012). So, the human resources fulfillment that has a complete competency must to do, either by qualitative or quantitative ways. 
Muhammad (2005) stated that the credibility and profesionalty of financial institution is developed if they have three elements, such as humanware, hardware, and software. Humanware is the persons that manage the institution started from highest level to the lowest level. The humanware must suitable either on quality side or quantity side. The hardware includes the production tools and physical equipment, such as machine, building, and the others. The software includes the non-physical things, such as procedure, system, and the others.

The development of human resources is concern with the activity and relationship control between the employes. They should show their optimal performance. The employes must to increase the competency and the technical skills to realize the goals that had been set in planning. The one thing that can be done to achieve it is by the human resources training.

According to the condition above, we can formulate the problem statements as follow: first, how is the situation and condition about the Islamic banking management in Indonesia? Second, how are the condition and the development of three Islamic banks in Jakarta? Third, how are the development's patterns on human resources development in three Islamic banks in Jakarta?

\section{Literature Review}

Islamic banking can be defined as a bank that operated based on profit sharing system that gives an advantage either for the society or the banks. The Islamic banking offers the justice in transactions, the ethical investment, and proposes the cooperative values and brotherhood in production, and avoids the speculative activities.

The human resources management is the empowerment, development, appraisal, the remuneration, and individual management of organization members or groups. Besides that, it also related with design and system implementation of planning, staffing, employee development, career management, performance's evaluation, employee compentation, and the good relationship in employee (Simamora, 2004).

Professionalism is based on the word of profession that has a meaning as a job based on skill and educated. Professionalism that the characters of professionals employee is a job, or title that must fulfill the certain qualification and personality (Komaruddin, 1994). On this research profession is job sector that based on educated skills, and certain personality such as honesty, loyalty, and the others. So, the professional human resources in Islamic business institution is a human resources that have a knowledge and skills in shariah, economics, and business practice. 
The development of human resources in Islamic banking is something that they have to do. The first job is with the selection of the employee to fulfill the position. The development and training existence in Islamic banking is obligatory, this things in the way to increase the productive working culture. The professionalism of human resources in Islamic banking is something that very strategi to increase the customer's loyalty and to make an efficient production process in Islamic banking industry.

One fundamental ways to make Islamic banking becomes credible is must be supported with human resources that qualify, competence, and professional. Professional means that the person needs special knowledge and skills to do that job. Profesionality means that a practical values of competence skills to manage the organization and do the job with effective and efficient (Muhammad, 2005). Profesionality can be measured just from physical appreance, but the most important show by the real performance from the activities. The Islamic and professional human resources have the qualification and competency that expertise in economics, banking, finance, and shariah.

In Indonesia the human resources problems is very complex, there are several indicators that show this things, such as: first, the difference between human resources competency with market of worker. Second, the distribution of populations is not equal. Third, the growth of workers is larger than the job's vacancy. Fourth, the asymmetric of public services need with the worker. Fifth, the market worker's information is not symectric. Sixth, the unemployment and poverty that makes a lower education and health.

There are several studies that have discussed about the human resources development. Eka Purwanda and Zaenal Muttaqien (2012) show the increasing Islamic human resources competency with the Islamic bank's leadership that visioner and adaptive. Muhammad (2003) show that the advantage of Islamic finance institution is determined by the credibel's human resources. We have an increasing empowerment strategy with the entrepreneurship and leadership empowerment in Islamic financial institution.

Siswanto (2012) conclude that to increase the advantage of Islamic bank's human resources is through the implementation of Qur'an-based human resources management. The result from this research is the implementation of Quran-based HRM and the employee satisfaction is positive. According to the Siswanto's research, this paper are going to show the human resources development problems using a phenomenological approach, so we expected that the increasing of human resources competency based on Quran can established the advantage of human resources Islamic banking. 
Tri Wikaningrum (2011) had identified the policy and development practice of human resources in Islamic banking and the influence to company's performance. The quantitative descriptive variable is the policy and human resources development, attitude, selection, training, and performance evaluation. The result shiw that the practice of human resources management is still not optimal, the training is still not optimal, the evaluation performance that not oriented on employee development. This paper are going to anaylize the influence of practical and policy in human resources management with the company's performance and employee development. So this paper are going to show the human resources development condition in Indonesian Islamic banking industry.

\section{Methods}

The research method is using qualitative methods using the phenomenological approach. This approach is selected because the research is targeted to identifying and mapping the comprehensive perception of respondent according to human resources development at three Islamic banks in Jakarta. So, with this method we hope that we can get the comprehensive information about the research subject to analyze the human resources development program in Islamic banks.

There are several steps on this approach, such as (Husserl, 1982): the first step on this research is intentional analysis. The second step is doing the epoche. The third step is eidetic reduction. The fourth step is the researcher concluding the research result to answer the question about the form and practice of human resources development in Islamic banks. The research framework can be shown on Figure 1.

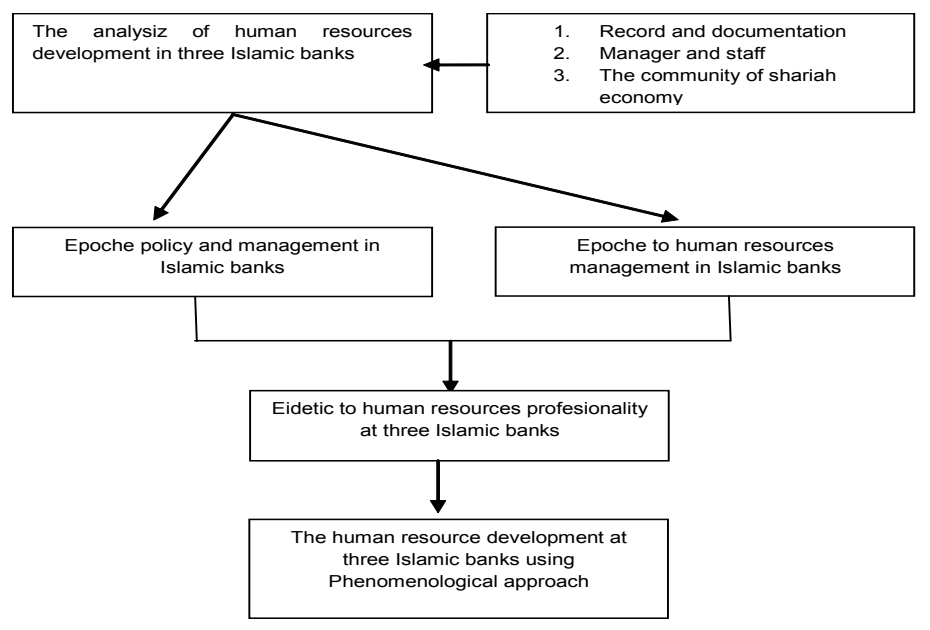

Figure 1. The Research Framework 
The Phenomelogical is described as what the feeling of individual or group related with his perception and experience. The feeling that established is called as phenomena (Prianti, 2011). The data that used on this research is based on manager and staff at three Islamic banks, such as Bank of Muamalat, Bank of BNI Syariah, and Bank of Shariah Mandiri. Also the data come from the interview with Head of Islamic Bank Department at Bank of Indonesia. To get depth information, this research using focus group discussion in several bank locations.

Moleong (1989) explain that on analysis data process in general have three relatied activities, such as: the data reduction, the data show, and the data verification to make a conclusion. On data analysis, the researcher doing the data reduction, after that show and compile the relevant data. Next is the data verification to make a conclusion.

\section{Discussion}

From the focus group discussion find there are several problems that need the solution, such as: first, the incomplete regulation for Islamic bank, this thing is become the problems so the Islamic banks can't operate optimally based on its characteristics. Second is the problem about the quality of human resources. Third is the problem about infrastructure.

Bank of BNI Syariah had recruitment for fresh graduate using professional hire institution. The human resources development based competency through recruitment process to all out performance, training, remuneration, and industrial relations. The target in human resources is maximizing the working culture, trust and brotherhood in all shariah employees. In Bank of Syariah Mandiri, the recruitmen process has three criteria, such as fresh graduate, professional employee for officer position, and management development program for fresh graduate. Every criterias has different competency according his job's position. The educational background can be varied, such as engineering, mathematics, economics, and the others. With the variation of educational background of course will be have an impact the competency's gap in understanding the banking product and operational.

Bank of BNI Syariah do the job evaluation every two until three years, this is suitable with business challenger. Besides that, also do the job analysis to see the suitableness job position with remuneration and assessment. The employee development's program is to make the trustworthy and brotherhood culture in working environment. The program and training is made based on the competency gap according the job's position. Standardized training curriculum is made based on the need on every job's position. 
Bank of BNI Syariah to do the evaluation for their employee is using performance appraisal evaluation. This method is using performance management system to increase the services and performance from Bank of BNI Syariah. This system is using the key performance indicator with computer system. The reason of application this system is to make an appraisal performance to be more accurate and can to go the effectivity of organization.

Bank of Shariah Mandiri doing the evaluation and revition through enhancement program, such as: certification program, public training, scholarship, and the others. The evaluation is supported by e-learning implementation that can be accessed by every employee. One form of evaluation program is assestment system in every level, such as middle management development program. If the employee can't pass the passing grade, so the employee must to involve the refreshment program. This refreshment program is doing every three month. Evaluation on this system is using the key performance indicator.

Bank of Muamalat Indonesia has fulfilled the officer need through his learning center in Muamalat Institute. The Muamalat Institute has doing the human resources quality that have a competency in Islamic banking practice, and also understand the shariah knowledge. The development of human resources is based on the organization needs and industry. The routine program in human resources development, such as: internal training, the periodical competency exam, the human resources development through MODP. So, it will create a new leader from internal organization.

From the discussion and interview we can make a several organization and human resources strategy that can be applied in Islamic bank, such as: first, realized the job analysis in every job's position either in head office or branch office. Second, the cooperation with academic institution to fulfill the human resources need. Third, the development and increase the human resources competency to fulfill the human resources need either in quality and quantity, so the banks can develop his business. Fourth, the development of human resources information shariah that based on competency.

The professional human resources at Islamic bank must to have the qualification and competency in economics, banking, and finance in one side, and combine it with the shariah knowledge. Because of that, the human resources at Islamic bank must to develop that competency.

The expertise of human resources will be developed in a good way, if they have the following criteria and type as follow: first, the shariah expertise that understand the economics, banking, and finance. Second, the economics, business, and finance 
expertise that understand the shariah knowledge. Third, the shariah, economics, banking and finance expertise.

According to Muhammad (2005), profesionality is an element key in Islamic bank's management. Nabi Muhammad SAW said "that Allah will be greatfull if one of you doing his job in a professional way" (HR. Baihaqi). The professional means that the individual will be in high motivation to finish their job in excellent result using the competency that he has.

There are several implications based on this research for Islamic banking industry, such as: first, should consider seriously and consequently the contribution of human resources studies to professionalism development. Second, give the chance to higher education institution to have managerial studies that can give a benefit to knowledge and practical development. Third, give a full attention with the human resources development condition at Islamic banks with the integrated framework of banking and shariah ethics. Fourth, do the cooperation between higher education instutiton and Islamic banking industry to develop the professional human resources.

Besides that, there are also several implications for regulator either for Bank of Indonesia or Financial Service Authority, such as: first, facilitate the policy that can support the human resources development at Islamic banking industry. Second, facilitate to decrease the implementation trap of integration knowledge (such as shariah knowledge with banking and financial knowledger) in every Islamic bank. Third, support the sinergity between the higher education institutions with the Islamic banking industry.

For higher education institution have to do several systemic and continuity actions in a framework of: first, mapping, organizing, facilitating the students need from the beginning of study. Second, formulate and response the human resources problems in a framework of academical studies. Third, support the students to have a contribution research to answer the Islamic banking industry problems.

This research also has an implication to the government either ministry of national education and culture or ministry of religious affair to keep in touch with the development of human resources for Islamic banking and financial institution need. The support can be formulated as curriculum since the high school until the university, so the Islamic economics and finance can develop rapidly in society.

\section{Conclusion}

This research find that the development and management from Islamic Banks has suitable with Islamic banking standars, because has fulfill the philosophy 
of Islamic economics, legal standing, vision and mission, the development policy, strategic target, etc. Besides that, it had established the human resources department with the supporting action from Bank of Indonesia in every Islamic bank. The qualification of humas resources in Islamic bank is based on Al-Qu'ran and sunnah. The human resources had passed the professional selection, after that the employee has a chance to follow the training either the soft skills training or hard skills training to improve the competency. The recruitment have three important criteria, such as: fresh graduate for tecnichal position, experience employee for officer position, and management development program for fress graduate that can fulfill the officer position.

There are several actions for decreasing the difference in human resources qualification, such as: open rectruitment at the university, do the training and monitoring, the banking staff program, micro banking academy, etc. The development pattern of human resources in Islamic banks basically divided into two, such as: the professional qualification based on shariah side, and the professional qualification based on tha business and banking side. The evaluation model and human resources in Islamic banks has eight substantial elements and procedures, such as job evaluation, job analysis, spiritual side, learning center, e-learning, refreshment, enhancement program, and value foundation. On this model, employee is not only as a target but also has a subject to evaluation process and human resources development.

The professionalism of human resources development in Islamic bank is should be: first, always integrated and empowerment of human resources principle to support the basic action, systematic, and contextual in the way to increase the effectivity and efficiency in Islamic banks; second, Islamic banks and conventional banks is should be together to improve the strategic role in economy; third, the consistency to have their own identity as Islamic business entity.

\section{References}

Ahmed, S. 2009. Islamic Banking Finance and Insurance: A Global View, Kualalumpur: AS. Noordeen.

Ali, S. \& F. Faryal. 2013. Islamic banking: Is the Confidence Level of Being an Islamic Banking Employee Better than Convention Banking Employee? An Exploratory Study Regarding Islamic Banking, Journal of Business Studies Quarterly, Volume 4, Number 3, pp. 42-64

Amirullah. 2008. Perguruan Tinggi: Pusat Pengembangan SDM dan Transformasi Pemahaman Ekonomi dan Perbankan Syariah, Jurnal Aplikasi Manajemen, Volume 6, Nomor 1, April 2008, pp. 45-60.

Antonio, M.S. 2001. Bank Syariah: Dari Teori ke Praktik. Jakarta: Gema Insani 
Press.

Arifin, Z. 2003. Dasar-dasar Manajemen Bank Syariah. Jakarta: AlvaBet.

Asnaini. 2008. Pengembangan Mutu SDM Perbankan Syariah: Sebagai Upaya Pengembangan Ekonomi islam. La_Riba, Jurnal Ekonomi Islam Vol.II, No.1, Juli 2008, pp. 51-68

Creswell, J.W. 2010. Research Design: Qualitative, Quantitative, and Mixed Methods Approach. Yogayakarta: Penerbit Pustaka Pelajar.

Darmawan, C. 2006. Kiat Sukses Manajemen Rasulullah: manajemen sumber daya insani berbasis nilai-nilai ilahiyah. Bandung: Khasanah Intelektual.

El-Seoudi, A.W.M. et.al. 2012. Human Resources in the Islamic Banks. Journal of Economic Theory 6 (2), pp. 66-69.

Gallagher, S. \& D. Zahavi. 2008. The Phenomeboligical Mind: in introduction to philosophy of mind cognitive science. London: Routledge.

Hafiduddin, D. \& H. Tanjung. 2003. Manajemen Syariah: Dalam Praktik. Jakarta: Gema Insani.

Herdiansyah, H. 2010. Metodologi Penelitan Kualitatif, Jakarta: Salemba Humanika.

Husserl, E. 2006. The Basic Problems of Phenomenology. Netherlands: Springer. Ivancevich, J.M. 2007. Human Resource Managament. New York: McGraw Hill.

Kuswarno, E. 2009. Fenomenologi: Konsepsi, Pedoman, dan Contoh Penelitiannya. Bandung: Widya.

Muhammad. 2005. Manajemen Bank Syariah. Yogyakarta: UPP AMP YKPN.

Moleong, L.J. 2011. Metodologi Penelitian Kualitatif. Bandung: Remaja Rosdakarya.

Noe, R.A. et.al. 2003. Human Resources Management. Boston: Mc Graw-Hill

Pheng, L.M. \& I.J. Detta. 2007. Islamic Banking \& Finance Law. Malaysia: Pearson Longman.

Simamora, H. 2004. Manajemen Sumber Daya Manusia. Yogyakarta: STIE YKPN.

Siswanto. 2011. Meningkatkan Daya Saing Sumber Daya Insani Perbankan Syariah melalui Implementasi Praktek Quran-Based HRM. Proceeding Forum Riset Perbankan Syariah V 2011.

Sugiyono. 2007. Metode Penelitian Kuantitatif Kualitatif dan R \& D. Bandung: Alfabeta.

Wikaningrum, T. 2011. Praktek dan Kebijakan Manajemen Sumber Daya manusia Pada Perbankan Syariah. Siasat Bisnis vol. 15 Januari 2011, pp. 32-44

Zubair, M.K. 2008. Akselerasi Pertumbuhan Bank Syariah di Indonesia. Jurnal Millah Vol.VIII, No.1, Agustus 2008, pp. 28-40 